\title{
Sistem Pendukung Keputusan Penentuan Penerimaan Raskin Menggunakan Metode Simple Additive Weighting (Studi Kasus Kelurahan Kota Uneng)
}

\author{
Petrus Wolo \\ Program Studi Teknik Informatika \\ Universitas Nusa Nipa \\ pwunipa@gmail.com
}

\author{
Alfridus Servasius M. Paseng \\ Program Studi Teknik Informatika \\ Universitas Nusa Nipa \\ Alfridus.paseng@yahoo.com
}

\author{
Yon Wiliam Roberth \\ Program Studi Teknik Informatika \\ Universitas Nusa Nipa \\ yonwilbert@gmail.com
}

\begin{abstract}
Abstrak - Program Beras Miskin atau Raskin merupakan salah satu program pemerintah untuk mengurangi beban pengeluaran dan perlindungan terhadap keluarga miskin melalui pendistribusian beras dengan jumlah dan harga tertentu. Dalam pendistribusian Raskin di kelurahan Kota Uneng sering kali ditemui kendala atau permasalahan karena masih dilakukan secara manual sehingga memungkinkan terjadinya penentuan secara subyektif oleh pihak pemerintah kelurahan dan belum mengacu pada kriteria yang telah ditentukan. Pada penelitian ini dibangun sistem pendukung keputusan untuk menentukan penduduk yang berhak menerima beras miskin dan penduduk yang benar-benar membutuhkan. Dalam penelitan penentuan penerimaan beras Raskin untuk keluarga tidak mampu menggunakan metode SAW (Simple Additive Weighting). SAW merupakan penjumlahan terbobot dari nilai kinerja pada setiap alternatif pada semua atribut dan membutuhkan proses normalisasi matriks keputusan (X) ke suatu skala yang dapat diperbandingkan dengan semua nilai alternatif yang ada sehingga dapat membantu pihak Kelurahan Kota Uneng dalam menentukan penduduk yang berhak menerima beras miskin dan penduduk yang benar-benar membutuhkan. Dengan demikian diharapkan penyaluran bantuan akan tepat sasaran. Hasil tersebut kemudian dapat ditampilkan berdasarkan nilai terbesar atau terkecil, sehingga memudahkan pengambil keputusan untuk memilih alternatif terbaik dari sejumlah alternatif.
\end{abstract}

Kata Kunci: Simple Additive Weighting (SAW), Sistem Pendukung keputusan, Raskin

\section{PENDAHULUAN}

Indonesia merupakan negara agraris, dimana rata-rata penghasilan didapat dari pertanian. Salah satu bidang pertanian yang paling maju adalah padi, yang menghasilkan beras sebagai makanan pokok. Banyaknya warga negara
Indonesia menyebabkan hasil panen beras dalam negeri tidak cukup untuk memenuhi kebutuhan warganya, sehingga memerlukan tambahan pasokan dari luar negeri [1]. Dalam pengambilan keputusan untuk menentukan kriteria keluarga miskin dibutuhkan sebuah sistem informasi yang dapat membantu mengatasi kecurangan yang dilakukan oleh pihak tertentu dalam menentukan calon penerima Raskin. Sistem pendukung keputusan merupakan bagian dari sistem informasi berbasis komputer yang dapat dipergunakan untuk mengatasi masalah ini. Sistem ini dapat mendukung pengambilan keputusan calon penerima Raskin berdasarkan kriteria-kriteria yang telah ditentukan. Cara kerja sistem ini mencakup seluruh tahap pengambilan masalah, memilih data yang relevan dan menentukan pendekatan yang digunakan dalam proses pengambilan keputusan sampai pemecahan dan solusi masalah.

Kelurahan Kota Uneng adalah salah satu instansi pemerintahan yang betugas dalam pelayanan masyarakat dan sebagai titik pendistribusian program Raskin. Namun pada praktek di lapangan, Kelurahan Kota Uneng dalam mengajukan rumah tangga penerima Raskin masih dilakukan secara manual, karena pada saat pengajuan daftar penerima Raskin tidak mengacu pada kriteria-kriteria yang berlaku.

Simple Additive Weighting (SAW) sering juga dikenal dengan metode penjumlahan terbobot. Konsep dasar metode SAW adalah mencari penjumlahan terbobot dari rating kinerja pada setiap alternatif dari semua atribut, metode SAW membutuhkan proses normalisasi matrik keputusan (x) ke suatu skala yang dapat diperbandingkan dengan semua rating alternatif yang ada, misalnya Sistem Penunjang Keputusan Untuk Menentukan Kelayakan Penerima Program Raskin [2], Sistem Pendukung Keputusan menentukan Penerima Beras Miskin [3], Sistem Pendukung Keputusan Menentukan Jumlah Beras Miskin [4], Sistem Pendukung Keputusan Penentuan Penyaluran Beras Bersubsidi [5], Menentukan Penerima Bantuan Beras Masyarakat Miskin (Raskin) [6], dan Sistem Pendukung Keputusan Untuk Penerimaan Raskin [7].

Dalam penelitian Sistem Pendukung Keputusan Penerimaan Raskin Untuk Keluarga Tidak Mampu di 
Kelurahan Kota Uneng Menggunakan Metode Simple Additive Weighting (SAW) ini proses pengambilan keputusan dilihat dari beberapa kriteria antara lain pekerjaan, penghasilan, jumlah tanggungan anak, kondisi rumah, dan luas bangunan. Hasil perhitungan kriteria tersebut kemudian dapat ditampilkan berdasarkan nilai terbesar atau terkecil, sehingga memudahkan pengambil keputusan untuk memilih alternatif terbaik dari sejumlah alternatif. Tujuan penelitan ini adalah untuk membantu pihak kelurahan Kota Uneng dalam menentukan calon penerima Raskin yang tepat sasaran dengan menggunakan metode Simple Additive Weighting (SAW).

\section{LANDASAN TEORI}

A. Sistem Pendukung Keputusan (Decision Support System)

Sistem Pendukung Keputusan (SPK) dibangun untuk mendukung solusi atas suatu masalah atau untuk suatu peluang serta digunakan untuk pengambilan suatu keputusan. Karakteristik dari sistem pendukung keputusan yaitu: mendukung proses pengambilan keputusan, mendukung pengambilan keputusan untuk masalah terstruktur, semi terstruktur serta beberapa keputusan yang saling berinteraksi, memiliki subsistem yang terintegrasi sehingga dapat berfungsi sebagai kesatuan sistem, memiliki dua komponen yaitu data dan model [8].

Adapun fase dalam pengambilan keputusan ditampilkan pada Gambar 1.

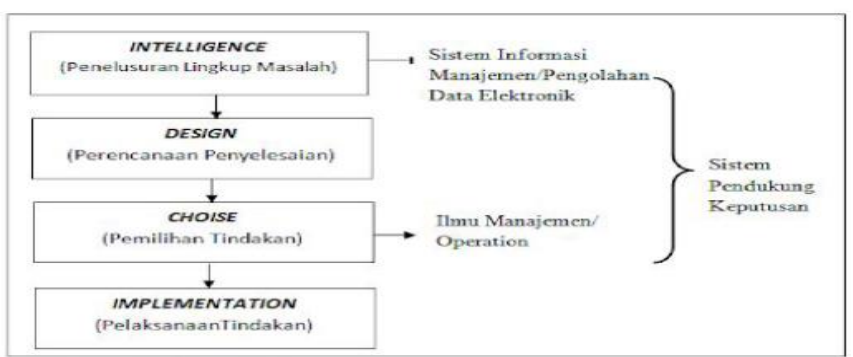

Gambar 1. Fase Proses Pengambilan Keputusan [8].

\section{B. Metode $S A W$ (Simple Additive Weighting)}

Metode SAW sering juga dikenal istilah metode penjumlahan terbobot. Konsep dasar metode SAW adalah mencari penjumlahan terbobot dari rating kinerja pada setiap alternatif dari semua atribut. Metode SAW membutuhkan proses normalisasi matriks keputusan (X) ke suatu skala yang dapat diperbandingkan dengan semua rating alternatif yang ada [9].

Diberikan persamaan sebagai berikut :

$\mathrm{r}_{\mathrm{ij}}= \begin{cases}\frac{\mathrm{x}_{\mathrm{ij}}}{\operatorname{Max}_{\mathrm{i}} \mathrm{x}_{\mathrm{ij}}} & \text { jika } j \text { adalah atribut keuntungan (benefit) } \\ \frac{\operatorname{Min}_{\mathrm{i}} \mathrm{x}_{\mathrm{ij}}}{\mathrm{x}_{\mathrm{ij}}} & \text { jika } j \text { adalah atribut biaya (cost) }\end{cases}$

Dimana rij adalah rating kinerja ternormalisasi dari alternatif Ai pada atribut $\mathrm{Cj} ; \mathrm{i}=1,2, \ldots, \mathrm{m}$ dan $\mathrm{j}=1,2, \ldots, \mathrm{n}$.
Nilai preferensi untuk setiap alternatif (Vi) diberikan sebagai berikut:

$$
V_{i}=\sum_{j=1}^{n} w_{j} r_{i j}
$$

Dimana:

$\begin{array}{ll}\mathrm{Vi} & =\text { nilai prefensi } \\ \mathrm{wj} & =\text { bobot rangking } \\ \mathrm{rij} & =\text { rating kinerja ternormalisasi }\end{array}$

Nilai Vi yang lebih besar mengindikasikan bahwa alternatif Ai lebih terpilih. Langkah-langkah dari metode SAW adalah:

1. Menentukan kriteria-kriteria yang akan dijadikan acuan dalam pengambilan keputusan, yaitu $\mathrm{C}$.

2. Menentukan rating kecocokan setiap alternatif pada setiap kriteria.

3. Membuat matriks keputusan berdasarkan kriteria (C), kemudian melakukan normalisasi matriks berdasarkan persamaan yang disesuaikan dengan jenis atribut (atribut keuntungan ataupun atribut biaya) sehingga diperoleh matriks ternormalisasi $\mathrm{R}$.

4. Hasil akhir diperoleh dari proses perankingan yaitu penjumlahan dari perkalian matriks ternormalisasi $\mathrm{R}$ dengan vektor bobot sehingga diperoleh nilai terbesar yang dipilih sebagai alternatif terbaik (A) sebagai solusi.

\section{METODOLOGI PENELITIAN}

Langkah-langkah yang dilakukan dalam penyelesaian masalah menggunakan metode Simple Additive Weighting (SAW) adalah sebagai berikut:

1. Menentukan kriteria (C) dan bobot untuk masing-masing kriteria rumah tidak layak huni.

2. Menentukan rating kecocokan setiap alternatif pada setiap kriteria.

3. Membuat matriks keputusan berdasarkan kriteria (C).

4. Normalisasi matriks berdasarkan persamaan yang disesuaikan dengan jenis atribut (atribut keuntungan ataupun atribut biaya) sehingga diperoleh matriks ternormalisasi $\mathrm{R}$.

5. Perkalian matriks normalisasi dengan bobot kriteria.

6. Melakukan proses perankingan untuk setiap alternatif $\left(\mathrm{V}_{\mathrm{i}}\right)$ dengan cara mengalikan nilai bobot $\left(\mathrm{w}_{\mathrm{i}}\right)$ dengan nilai rating kinerja ternormalisasi $\left(\mathrm{r}_{\mathrm{ij}}\right)$

\section{HASIL DAN PEMBAHASAN}

Sesuai dengan langkah-langkah penelitian di atas, pada pembahasan berikut ini akan dibahas tentang proses pengambilan keputusan penerimaan Raskin untuk keluarga tidak mampu di kelurahan Kota Uneng menggunakan Metode Simple Additive Weighting (SAW). Langkah awal adalah menentukan kriteria dan bobot masing-masing 
kriteria penerimaan raskin untuk keluarga tidak mampu di kelurahan Kota Uneng dengan mengikuti aturan standar yang berlaku di kelurahan Kota Uneng. Hasilnya ditampilkan pada Tabel 1.

Tabel 1. Data Kriteria.

\begin{tabular}{lllr}
\hline $\begin{array}{c}\text { Kode } \\
\text { Kriteria }\end{array}$ & Nama Kriteria & Atribut & Bobot \\
\hline C1 & Pekerjaan & Cost & 25 \\
\hline C2 & Penghasilan & Cost & 30 \\
\hline C3 & $\begin{array}{l}\text { Jumlah } \\
\text { Tanggungan }\end{array}$ & Benefit & 15 \\
& Anak & & \\
\hline C4 & Kondisi Rumah & Cost & 20 \\
\hline C5 & Luas Bangunan & Cost & 10 \\
\hline
\end{tabular}

Setelah menentukan kriteria dan bobot, di tahap selanjutnya masing-masing sub kriteria ditentukan juga bobotnya. Hasilnya ditampilkan pada Tabel 2, Tabel 3, Tabel 4, Tabel 5, dan Tabel 6.

Tabel 2. Sub Kriteria C1.

\begin{tabular}{lr}
\hline \multicolumn{1}{c}{ C1 } & \multicolumn{1}{c}{ Bobot } \\
\hline PNS & 15 \\
\hline Wiraswasta & 30 \\
\hline Petani & 50 \\
\hline Buruh & 70 \\
\hline Pengangguran & 100 \\
\hline
\end{tabular}

Tabel 3. Sub Kriteria C2.

\begin{tabular}{lr}
\hline \multicolumn{1}{c}{ C2 } & Bobot \\
\hline$>=2.500 .000$ & 15 \\
\hline $2.000 .000-2.500 .000$ & 30 \\
\hline $1.000 .000-2.000 .000$ & 50 \\
\hline $500.000-1.000 .000$ & 70 \\
\hline$<=500.000$ & 100 \\
\hline
\end{tabular}

Tabel 4. Sub Kriteria C3.

\begin{tabular}{|c|c|}
\hline C3 & Bobot \\
\hline$<=2$ & 15 \\
\hline 3 & 30 \\
\hline 4 & 50 \\
\hline 5 & 70 \\
\hline$>6$ & 100 \\
\hline
\end{tabular}

Tabel 5. Sub Kriteria C4.

\begin{tabular}{lr}
\hline \multicolumn{1}{c}{ C4 } & Bobot \\
\hline Tembok Keramik & 15 \\
\hline Tembok Plester & 30 \\
\hline Tembok Bata & 50 \\
\hline Bambu Plester & 70 \\
\hline Bambu Tanah & 100 \\
\hline
\end{tabular}

Tabel 6. Sub Kriteria C5.

\begin{tabular}{lr}
\hline \multicolumn{1}{c}{ C5 } & Bobot \\
\hline$>=180 \mathrm{~m}^{2}$ & 15 \\
\hline $150-180 \mathrm{~m}^{2}$ & 30 \\
\hline $120-150 \mathrm{~m}^{2}$ & 50 \\
\hline $100-120 \mathrm{~m}^{2}$ & 70 \\
\hline$<=100 \mathrm{~m}^{2}$ & 100 \\
\hline
\end{tabular}

Tahap selanjutnya menentukan data alternatif. Data alternatif merupakan alternatif yang akan dihitung nilainya dan dipilih sebagai alternatif terbaik. Data alternatif biasanya berisi kode dan nama. Hasilnya ditampilkan pada Tabel 7.

Tabel 7. Data Alternatif.

\begin{tabular}{ll}
\hline Kode Alternatif & Nama Alternatif \\
\hline A1 & Martin \\
\hline A2 & Mustafa \\
\hline A3 & Hasan \\
\hline
\end{tabular}

Setelah menyiapkan data, sekarang waktunya melakukan perhitungan SAW. Pada tahap ini anda mengubah nilai pada alternatif sesuai bobot, sehingga diperoleh data seperti Tabel 8 .

Tabel 8. Tahap Analisis.

\begin{tabular}{lccccc}
\hline Kode Alternatif & C1 & C2 & C3 & C4 & C5 \\
\hline A1 & 50 & 50 & 30 & 70 & 100 \\
\hline A2 & 30 & 30 & 70 & 50 & 50 \\
\hline A3 & 100 & 100 & 70 & 100 & 100 \\
\hline
\end{tabular}

Berikut cara perhitungannya :

- $\mathrm{C} 1=$ cost, $\min =30$

$\mathrm{A} 1=30 / 50=0,6$

$\mathrm{A} 2=30 / 30=1$

$\mathrm{A} 3=30 / 100=0,3$

- $\mathrm{C} 2=$ cost, $\min =30$

$\mathrm{A} 1=30 / 50=0,6$

A $2=30 / 30=1$

A $3=30 / 100=0,3$ 
- $\mathrm{C} 3=$ benefit, $\min =70$

$\mathrm{A} 1=30 / 70=0,42$

$\mathrm{A} 2=70 / 70=1$

$\mathrm{A} 3=70 / 70=1$

- $\mathrm{C} 4=$ cost, $\min =50$

$\mathrm{A} 1=50 / 100=0,71$

$\mathrm{A} 2=50 / 50=1$

$\mathrm{A} 3=50 / 100=0,5$

- $\mathrm{C} 5=$ cost, $\min =50$

$\mathrm{A} 1=50 / 100=0,5$

$\mathrm{A} 2=50 / 50=1$

A $3=50 / 100=0,5$

Tahap yang terahkir adalah tahap perangkingan yaitu kita mengkalikan bobot kriteria dengan setiap baris matriks nilai normalisasi.

$$
\begin{aligned}
\mathrm{A} 1= & (0,6 \times 25)+(0,6 \times 30)+(0,42 \times 15)+(0,71 \times 20)+(0,5 \\
& \times 10) \\
= & 15+18+6,3+14,2+5 \\
= & 58,5 \\
\mathrm{~A} 2= & (1 \times 25)+(1 \times 30)+(1 \times 15)+(1 \times 20)+(1 \times 10) \\
= & 25+30+15+20+10 \\
= & 100 \\
\mathrm{~A} 3= & (0,3 \times 25)+(0,6 \times 30)+(1 \times 15)+(0,5 \times 20)+(0,5 \times \\
& 10) \\
= & 7,5+9+15+10+5 \\
= & 46,5
\end{aligned}
$$

Tabel 9. Hasil Perhitungan Perengkingan.

\begin{tabular}{lrr}
\hline Kode Alternatid & Total & Rangking \\
\hline A1 & 58,5 & 2 \\
\hline A2 & 105 & 1 \\
\hline A3 & 46,5 & 3 \\
\hline
\end{tabular}

Dari perhitungan di atas didapat A2 (Chyo) merupakan nilai terbesar sehingga diperoleh sebagai alternatif terbaik.

\section{KESIMPULAN}

Berdasarkan hasil dan pembahasan di atas, dapat disimpulkan bahwa sistem pendukung keputusan penerimaan Raskin untuk keluarga tidak mampu menggunakan metode SAW dapat membantu pihak Kelurahan Kota Uneng dalam menentukan penduduk yang berhak menerima beras miskin, agar dalam proses pelaksanaan pemberian bantuan dapat diserahkan kepada penduduk yang benar-benar membutuhkan. Dengan demikian diharapkan penyaluran bantuan dapat tepat sasaran. Hasil tersebut kemudian dapat ditampilkan berdasarkan nilai terbesar atau terkecil, sehingga memudahkan pengambil keputusan untuk memilih alternatif terbaik dari sejumlah alternatif.

\section{REFERENSI}

[1] Rini, S. (2014). Sistem Pendukung Keputusan Seleksi Penerimaan Beras Untuk Keluarga Miskin Dengan Metode Simple Additive Weighting. Jurnal Sarjana Teknik Informatika, Vol. 2, No. 2.

[2] Siswono dkk. (2017). Sistem Penunjang Keputusan Untuk Menentukan Kelayakan Penerima Program Raskin Menggunakan Metode Simple Additive Weighting (SAW) Pada Kelurahan Kesambi. Jurnal Digit, Vol. 7, No.1.

[3] Pratama dkk.. (2017). Sistem Pendukung Keputusan Menentukan Penerima Beras Miskin (Raskin) Menggunakan Metode Simple Additive Weighting (SAW) (Studi Kasus: Desa Kerjo Lor, Ngadirojo, Wonogiri). Jurnal SCRIPT, Vol. 4, No. 2.

[4] Angrawati dkk. (2016). Sistem Pendukung Keputusan Menentukan Jumlah Beras Miskin Menggunakan Metode Simple Additive Weight (SAW). semanTIK, Vol. 2, No. 1.

[5] Akbar dkk. (2014). Sistem Pendukung Keputusan Penentuan Penyaluran Beras Bersubsidi Menggunakan Metode Analytical Hierarchy Process (AHP). Jurnal Media Infotama, Vol. 10, No. 2.

[6] Firdyana dkk. (2017). Penerapan Metode Weighted Product Untuk Menentukan Penerima Bantuan Beras Masyarakat Miskin (Raskin). Prosiding Seminar Ilmu Komputer dan Teknologi Informasi, Unversitas Mulawarman.

[7] Ferawati, K. (2015). Implementasi Metode Analytical Hierarchy Process (AHP) Dalam Sistem Pendukung Keputusan Untuk Penerimaan Raskin Di Kelurahan Simpang Baru Panam. SATIN - Sains dan Teknologi Informasi, Vol. 1, No. 1.

[8] Nofriansyah (2014). Konsep Data Mining vs Sistem Pendukung Keputusan. Yogyakarta: Deepublish.

[9] Kusumadewi dkk. (2006). Fuzzy Multi-Attribute Decision Making (Fuzzy MADM). Yogyakarta: Graha Ilmu. 